\title{
USE OF NEW TECHNOLOGIES FOR THE SYSTEMATIC NAUTICAL CARTOGRAPHIC MAPPING OF THE PARAGUAY RIVER WATERWAY
}

\author{
Paulo Pereira Oliveira MATOS ${ }^{1}$ \\ Juarez Cerqueira FERREIRA ${ }^{1}$ \\ Victor Hugo do Espírito Santo CONCEIÇÃO ${ }^{1}$
}

\begin{abstract}
One of the main cargo corridors of the Brazilian West region is the Paraguay River. Currently, the Paraguay River Waterway moves more than seven million tons of cargo, being the second largest waterway for cargo movement in Brazil. However, for the quick and safe transport of goods it is essential to have a proper, systematic and complete mapping of the river bed. This work, in charge of the Brazilian Navy and dating back to the Nautical Cartographic Basic Plan of 1935, is performed with the construction of official nautical documents, aiming the navigation safety. These cartographic documents, called Official Nautical Charts, are the result from the mapping process, originated from the collection of bathymetric data on specific spots. This collection used always the most modern technologies available and recently, single beam echo-sounders and accurate positioners. Today new technologies are available, including the multi-beam echo-sounder, equipment with several advantages, allowing, among others, the full coverage of the riverbed. This article describes this paradigm shift for the collection of bathymetric data in Paraguay River basin, presenting the preliminary findings and conclusions from the use of this technology.
\end{abstract}

Key words: Nautical cartography. Hydrography. Multi-beam echo sounder. Navigation safety.

\section{Resumo}

\section{Utilização de novas tecnologias para o mapeamento cartográfico náutico sistemático da Hidrovia do Rio Paraguai}

Um dos principais corredores de movimentação de cargas da região CentroOeste brasileira é o rio Paraguai. Atualmente, a Hidrovia do Rio Paraguai movimenta mais de sete milhões de toneladas de carga, sendo a segunda maior hidrovia em movimentação de cargas no Brasil. Porém, para que estas cargas sejam transportadas de forma rápida, econômica e segura, é imprescindível um correto, sistemático e completo mapeamento do leito do rio. Esta responsabilidade, a cargo da Marinha do Brasil, remonta ao Plano Básico Cartográfico Náutico, de 1935, e materializa-se através da construção de documentos náuticos oficiais, tendo por objetivo a segurança da navegação. Estes documentos, chamados de cartas náuticas oficiais, resultam do processo cartográfico que tem, por origem, a coleta de dados batimétricos in loco. Esta coleta (sondagem) sempre se utilizou das mais modernas tecnologias disponíveis sendo, a mais recente, a utilização de ecobatímetros monofeixe e posicionadores precisos. No entanto, novas tecnologias apresentam-se atualmente, entre elas o ecobatímetro multifeixe, equipamento que possui diversas vantagens, entre elas permitir o recobrimento total do leito do rio. Este artigo descreve esta quebra de paradigma na coleta de dados batimétricos na calha do rio Paraguai, apresentando os primeiros resultados e conclusões da utilização desta tecnologia.

Palavras-chave: Cartografia náutica. Hidrografia. Ecobatímetro multifeixe. Segurança da navegação.

\footnotetext{
${ }^{1}$ Centro de Hidrografia da Marinha - CHM. Rua Barão de Jaceguai, s/no - 28040-900 - Niterói - RJ,

Brasil. E-mails: \{paulo.matos, juarez.ferreira\}@marinha.mil.br, kafos1234@gmail.com
} 


\section{INTRODUCTION}

The Brazilian National Waterways Transportation Agency (ANTAQ) (2010) denominated as "Paraguay River Waterway" the section of the Paraguay River in the Brazilian national territory between Cáceres/Mato Grosso State and the mouth of the Apa River/Mato Grosso do Sul State, covering approximately 1,270 kilometers. Being one of the main cargo corridors in the Brazilian West region, the Paraguay River Waterway currently moves more than seven million tons of cargo, being the second largest cargo handling waterway in Brazil. This waterway, besides draining the agricultural production of the western Brazilian States, serves as a natural connection to the sea for Bolivia and Paraguay. In 2014, the Paraguay River Waterway handled totally 7.1 million tons of cargo (ANTAQ, 2015), as seen in Table 1:

\section{Table 1 - Transport of cargoes (in t) and TKU by waterways in 2014}

\begin{tabular}{lrrrrrr}
\hline \multicolumn{1}{c}{ Waterway } & \multicolumn{3}{c}{ Inland Navigation } & & & \\
& State & Interstate & International & Total (t) & $\begin{array}{c}\text { Average } \\
\text { Distance } \\
(\mathrm{km})\end{array}$ & TKU Total \\
\hline rio Madeira & 0 & 4.784 .856 & 781 & 4.785 .638 & 1.071 & 5.123 .072 .998 \\
rio Solimões-Amazonas & 3.077 .063 & 7.476 .357 & 16.207 & 10.569 .627 & 554 & 5.853 .836 .436 \\
rio Tocantins-Araguaia & 906.264 & 2.357 .562 & 0 & 3.263 .827 & 207 & 676.569 .427 \\
Hidrovias do Sul & 4.105 .384 & 0 & 0 & 4.105 .384 & 271 & 1.114 .450 .862 \\
rio Paraguai & 0 & 0 & 7.148 .005 & 7.148 .005 & 513 & 3.670 .402 .550 \\
rio São Francisco & 0 & 12.812 & 0 & 12.812 & 576 & 7.373 .818 \\
rio Paranán-Tietê & 3.125 .106 & 1.010 .112 & 508.911 & 4.644 .129 & 140 & 649.381 .764 \\
\hline
\end{tabular}

Source: ANTAQ (2015).

It is worth mentioning the investment forecast and the expectation for the expansion of the cargo handling capacity in this waterway. The Brazilian Strategic Waterway Plan, a document prepared by the Ministry for Transports (2013), foresees a total amount of general cargoes of 10,871,000t in 2023 and 14,883,000t in 2031 transported on the Waterway.

A correct, systematic and complete mapping of the most important regional waterways is essential for the quick, economic and safe transport of these cargos. In this frame, the Brazilian Navy, according to Decree-Law no. 243/67, also exerts in this region its assignment to plan and to execute the nautical themed cartography. It thus contributes unequivocally to the safety of navigation, in accordance with international conventions and regulations, such as the Safety of Life at Sea Convention - SOLAS, signed in 1974.

This responsibility, in charge of the Directorate for Hydrography and Navigation, goes back to the Basic Nautical Chart Plan from 1935, and is materialized by the construction of official nautical documents, aiming the safety of navigation. These documents, called officially Nautical Charts, are the result of the cartographic process originated with the collection of bathymetric data in loco. This collection (technically called Bathymetric Soundings), used always the most advanced technologies available, and the most recent ones are the single-beam echo-sounders and precise positioners.

The initial step of the cartographic process for the systematic nautical mapping of the Paraguay River Waterway is the acquisition of bathymetric data by vessels and 
motor-boats subordinated to the Brazilian Nautical Signal Service of the West (SSN6). Figure 1 shows the area of work by SSN-6 in the region. Until 2014 the data collection was carried out basically with single-beam echo-sounders, which uses the characteristics of the sound propagation to acquire geo-referenced point depth information. However, with the advent of new technologies, such as multi-beam bathymetry, as well as the acquisition of "State-of-the art" equipment by SSN-6, the bathymetric data collection (also known as bathymetric sounding) became much more effective and efficient, serving as a model for surveys conducted in all other Brazilian waterways.

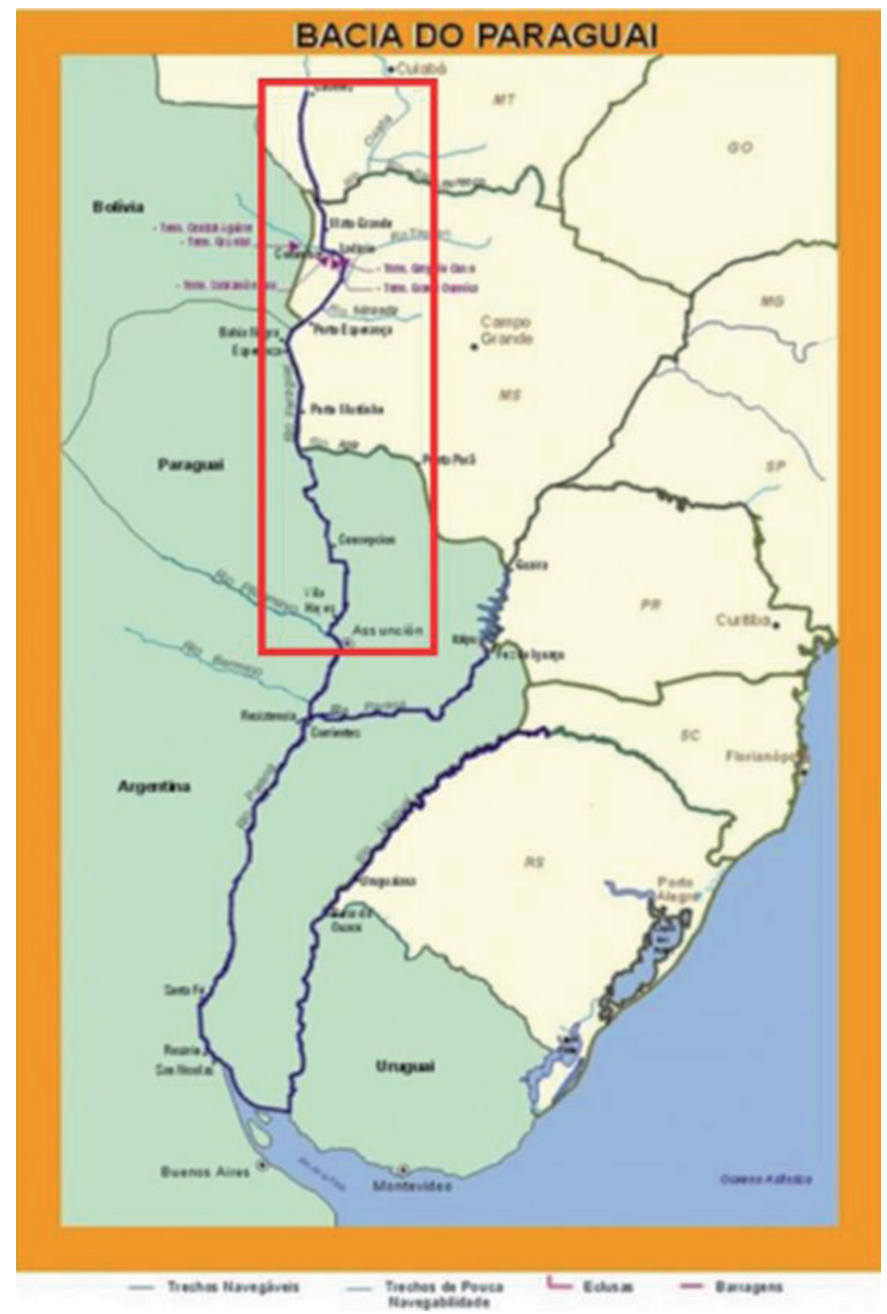

Figure 1 - Area covered by the Brazilian Hydrography, where multi-beam technology will be used for the systematic bathymetric survey

Source: Author. 


\section{OBJECTIVE}

The objective of this article is to describe the paradigm change for the collection of bathymetric data in the Paraguay River Waterway, presenting the first results and conclusions on the use of a new technology for the data collection: the multi-beam echo-sounder.

\section{MATERIALS AND METHODS}

Miguens (1996) defines an echo-sounder as a simple sound propagation instrument, which has a device which measures the time elapsed between the emission of a sound pulse and the reception of its echo, after reflecting in the background. Knowing this time (whose half value corresponds to the time necessary for the impulse to reach the bottom) and assuming an average velocity of propagation from the impulse (usually of $1,500 \mathrm{~m} / \mathrm{s}$ ), the local depth is obtained, directly, displayed visually or digitally, or even indicated on special recording paper (or LCD display), which shows the background profile.

The first equipment used was the single beam echo-sounder. These equipments dominated the Hydrography for decades, replacing the old hand-pipes with the direct measurement of the local depth. Consisting primarily of a transducer, a receiver and a graphic recorder, the single beam echo-sounder emits a sound beam at a time. So when the return beam is received (known as Echo) by indirect measurements, the local depth is obtained. When the equipment is connected to a positioner, this point depth is geo-referenced, which is fundamental for its use in the cartographic update.

In order to maximize the performance of the single beam echo-sounder, the acquisition is performed perpendicular to lines of the same depth, known as "Isolines" or "Iso-bathymetrics". With this technique it is possible to know the gradient of the riverbed, identifying possible dangers to the safety of navigation.

All the recent Brazilian nautical cartography, until the middle of the 90 's, used primary subsidies data derived from this technology. Many nautical charts still in force, in Brazilian Jurisdictional Waters, were made using this technology.

With the worldwide development of bathymetric data acquisition technology, new equipments were presented to the scientific community, among them the multibeam echo-sounder. This technology represented an important paradigm change in relation to traditional bathymetry. Multi-beam echo-sounders are sensors that generate narrow beam sequences whose depth is the result of the measurement combination of the beam travel time and the emission and reception angles from the acoustic signal. Some multi-beam systems are capable to obtain more than 50 scan profiles per second, getting several depth measurements. From the same acoustic feedback signal, information such as background geomorphology can be inferred after appropriate radiometric and geometric backscatter reduction and its correlation with consistent background samples. Figure 2 shows the difference in data acquisition between the two devices: 

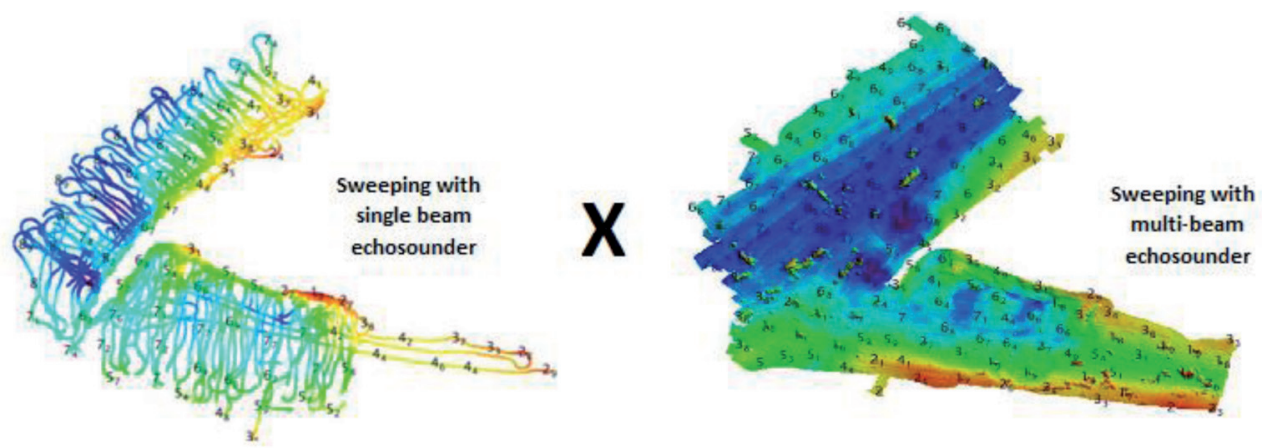

\section{Figure 2 - Difference in data acquisition between single beam and multi-beam echo-sounders}

Source: Author.

Multi-beam echo-sounders are able to inform the depth in a region, rather than punctually - which is, in fact, the great difference between the two technologies. So the full sweeping of large areas becomes faster and more complete, since multi-beam scanning allows the complete imaging of the river floor - which the single beam technology cannot provide, even when the spacing between the sounding lines is minimized. However both technologies are complementary, although the multi-beam echo-sounder is clearly an evolution of the single beam echo-sounder, allowing the production of high-resolution bathymetric surfaces.

In order to maximize the performance of the multi-beam echo-sounder, the data acquisition is made in the same direction as the iso-bathymetric lines. The use of this technique allows the sensor operation in regions with the same velocity of sound at the surface and permits to know the entire riverbed, identifying dangers spots and obstructions to the safety of navigation.

The multi-beam acoustic systems purchased by the Brazilian Navy and available for use in the Paraguay River Waterway operate in the frequency range of 12 to 400 $\mathrm{kHz}$ and are capable to perform consistent bathymetric surveys which meet the specified Hydrographic Surveys (LH) Standards and Orders as stated in the Special Publication S-44 - Specifications of the International Hydrographic Organization for Hydrographic Surveys.

The multi-beam echo-sounder is suitable for surveys where a high level of detail from the bottom surface is required or a complete ensonification of the bottom (special order surveys as stated in publication S44, navigation channels, location of obstacles and objects, location of submerged ducts, etc). Thereby it is suitable for surveys at port access channels, narrow passages and areas where the clearance below the keel is critical.

In order to enable the application of this new technology in the Pantanal region, the Brazilian Navy, through SSN-6, started to conduct bathymetric surveys using the Kongsberg EM-2040C Dual Head multi-beam echo-sounder, shown in figure 3, suitable for inland waters, which provides a very accurate three-dimensional view of the riverbed. Thus, the critical places for navigation can be known more accurately, allowing a welldefined cartographic representation and the installation of an effective buoy system. 

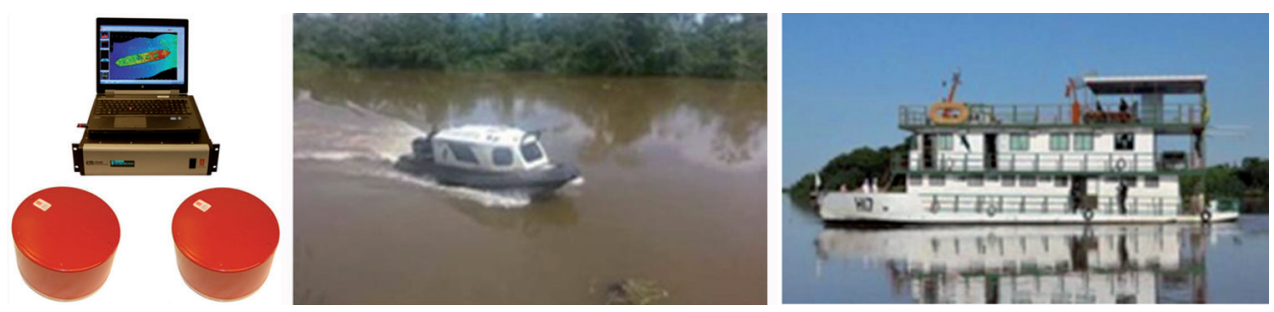

Figure 3 - (Left), Kongsberg EM 2040 dual head multi-beam echosounder. (Center) a motorboat equipped with the multi-beam system. (Right) support Hydro-Oceanographic Ship Caravelas

Source: Author.

The installation and configuration procedure of the echo-sounder was done by two Officers (Cartographic engineers) of SSN-6, together with representatives from the manufacturer Kongsberg Maritime AS, which allocated two engineers for this work, including the geometric alignment of all components from the system, in a procedure known as "Definition of offsets".

\section{RESULTS AND DISCUSSION}

As previously mentioned, all the maps produced until now on the Paraguay River Waterway, used data from single beam echo-sounders. An example of the current processing is shown in figure 4, extracted from the analysis of a survey made in May 2016 by the Navy Hydrography Center:

Referring to the multi-beam surveys, they have already been carried out in approximately $100 \mathrm{~km}$ of the channel from the Paraguay River, and data from the adjacent Nautical Charts were sent to the Hydrography Center, responsible for the construction and updating of these maps in Brazil.

Situation in March 2016:

a) Complete nautical charts: 3319, 3332, 3355, 3358, 3433 and 3442. (88 km surveyed);

b) Partial sections: 3300, 3301, 3359 and 3366. (4 km surveyed); and

c) Surveys in progress: 3395 and 3426. (2 km surveyed). 


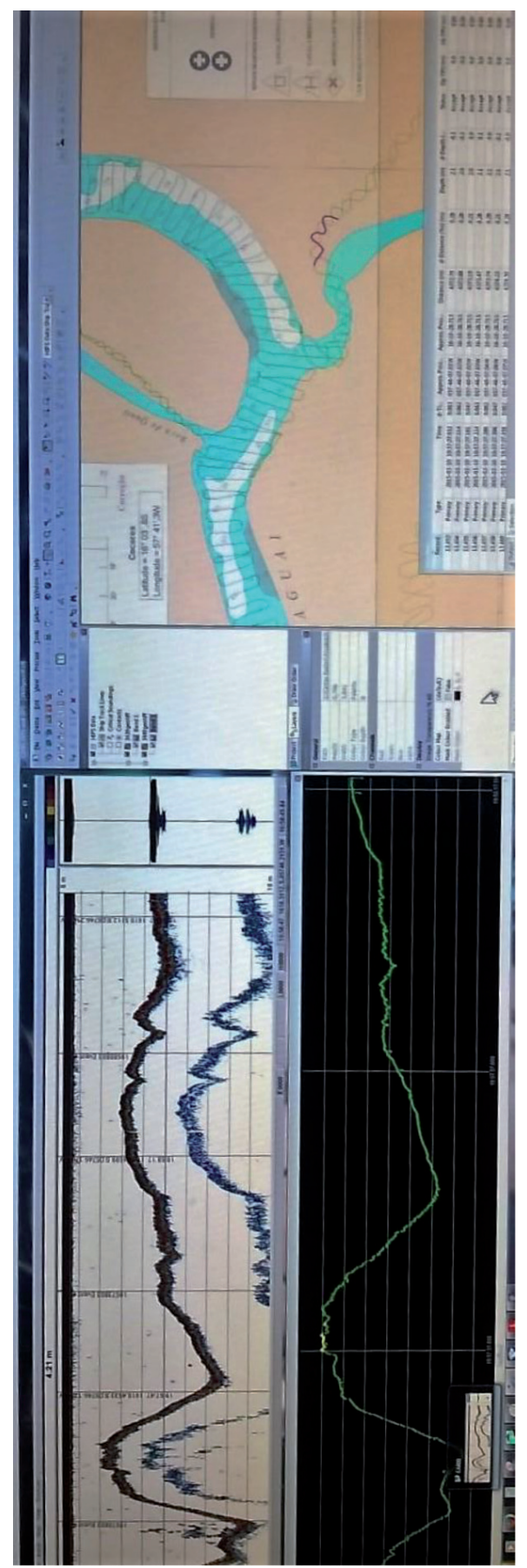

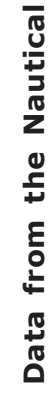

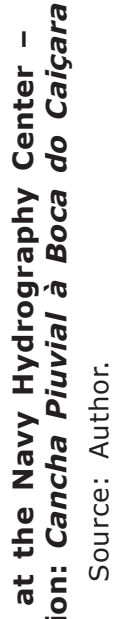

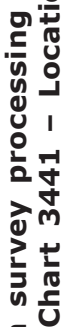

ह

$\frac{0}{\frac{0}{5}}$

I

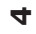

는 
Figure 5 shows a synthesis of the first results obtained with the use of this new technology:
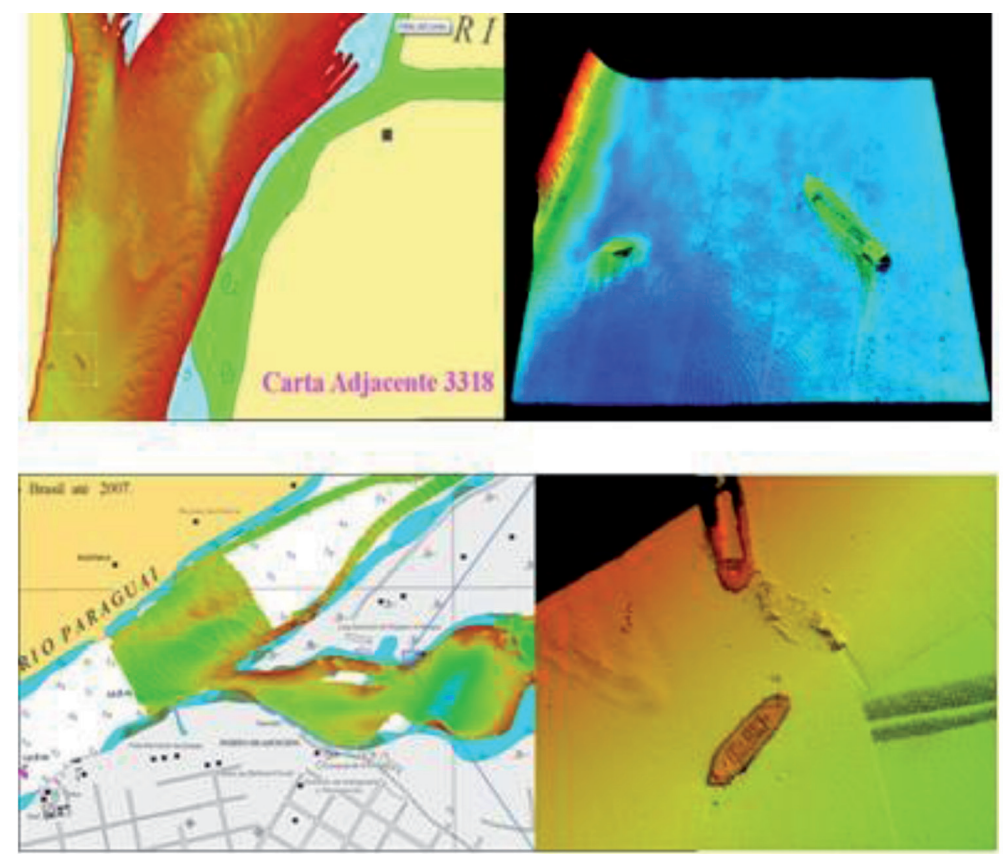

Figure 5 - Results obtained with the use of multi-beam echo-sounders:
location of obstacles in the Paraguay riverbed

Source: Author.

The first results are encouraging with surveys which detected dangers to navigation not yet mapped, such as sunken hulls and mobile sandbars, among other obstacles. So the safety for navigation was strengthened, as new bathymetric surveys were carried out and new editions of nautical charts were published. Although only about $10 \%$ of the Paraguay River Waterway has been surveyed with this new technology, the progress made in the cartographic mapping is perceptible.

It is noteworthy that the technology described above does not cause damage to the environment and cases of wildlife mortality due to exposure to sound waves have not been directly and objectively observed. These waves do not produce pollution and do not influence the water quality of rivers, lakes and any other bodies of water where they have been used.

The use of multi-beam technology will allow the ships subordinated to SSN-6 and, consequently, to the Brazilian Navy, the rationalization of the bathymetric surveys conducted in the Paraguay River bed, with a faster execution and greater detailing of the river bottom. Obstacles previously undetected can be observed, resulting in a greater reliability of the nautical charts of the region, as well as increase the safety of the local navigation, a major objective of the Brazilian Nautical Cartography. With increased safety to navigation, ships loaded with more cargo - and of greater draft - 
will be able to travel in the Paraguay river waterway, impelling the local economy. Similarly, the insurance price for cargo transportation tends to decrease, thus reducing the overall cost for the production and commerce of the country.

\section{CONCLUSIONS}

This study has an innovative character, since, although civil companies already use this technology in the region, the bed of the Paraguay river had not yet been fully surveyed officially, by the Brazilian Navy, with this new technology. Therefore, all the official nautical cartography of the Paraguay River Waterway will be revisited, increasing the accuracy of information and improving the safety of navigation throughout the region. The survey planning foresees the full coverage of the Northern and Southern sections of the Paraguay River, from Ladário/Brazil to Asunción/Paraguay, using multibeam technology.

Following the success on the use of multi-beam echo-sounders by the Brazilian Navy in the Paraguay River Waterway, other waterways will be contemplated with the operation of ships equipped with such equipment, as the Madeira, Amazonas and Solimões Waterways. With this effort, it is expected to reduce the time lapse between subsequent cartographic updates, covering larger navigable regions in less time and with greater precision.

\section{REFERENCES}

AGÊNCIA NACIONAL DE TRANSPORTE AQUAVIÁRIO (ANTAQ). Superintendência de Navegação Interior. Transporte de Cargas na Hidrovia do Paraguai 2010. Brasília, 2011. 14p.

Superintendência de Desempenho, Desenvolvimento e Sustentabilidade.

Indicadores de Tonelada Útil ( $\mathrm{t}$ ) e Tonelada por Quilômetro Útil (TKU) do Transporte de Cargas na Navegação Interior e na Cabotagem. Brasília, 2015. 39p.

MIGUENS, A. P. Navegação: A Ciência e A Arte, Volume III-Navegação Eletrônica e em Condições Especiais. Manual de Navegação, DHN, 1996.

MINISTÉRIO DOS TRANSPORTES (MT). Relatório de Diagnóstico e Avaliação do Plano Hidroviário Estratégico. Brasília, 2013. 861 p. 